\title{
名誉会員の推 戴
}

4 月 1 日(土)の第 22 回通常総会(会場：愛知県中小企業センター 講堂）に打いて，定款第 9 条の規定に基づき，下記 10 氏が名誉会 員に推薦され，藤巻会長から名誉会員証が贈呈された(御年齢順).

$\begin{array}{llllll}\text { 山 } & \text { 本 } & & \text { 亮 } & \text { 氏 } & \text { 石 侬 喜 明 氏 } \\ \text { 赤 } & \text { 堀 } & \text { 四 } & \text { 郎 } & \text { 氏 } & \text { 福本寿一郎 氏 } \\ \text { 野 } & \text { 副 } & \text { 鉄 } & \text { 男 } & \text { 氏 } & \text { 小幡 弥太 郎 氏 } \\ \text { 奥 } & \text { 田 } & & \text { 東 氏 } & \text { Prof. Melvin Calvin } \\ \text { 二 } & \text { 二 国 } & \text { 郎 氏 } & & \text { Prof. Feodor Lynen }\end{array}$

終身 会 員

去る 3 月 27 日に開催された本会第 60 回評議員会に扎いて，定款第 9 条 -2 項の規定に基づいて，下記 23 名の方々が終身会員として承認されました。(順不同)

\section{4東北支部》}

葛西文造氏

《関東支部

関戸涊平氏 田泾健次郎氏 務台蔵人氏

藤原彰夫氏
永原太郎氏 東 秀 雄氏 中野政弘氏
梅田勇雄氏 信 䟴 策氏 柴沼忠三氏
小川政禧氏 北原增雄氏鳥山史郎氏

\section{《関西支部}

貴志雪太郎氏 篠崎值一氏 堀江重美氏 福渡七郎氏下村弘氏麦林樽太郎氏

《西日本支部

三山良輔氏山藤一雄氏佐藤静一氏

\section{二 그..}

\section{新しい味の肉を求めて}

肉の「御三家」と言忘ば, らつうでは牛肉, 豚肉, 緬 山羊肉をさす、慆肉はミートではない. 1974 年の統計 によると，世界での肉の生産量は牛肉； 4200 万トン， 豚肉; 4250 万トン, 山羊肉; 1400 万トン, 羊肉; 540 万トン, 馬肉; 70 万トンで, 鷄肉は 2070 万トンであっ た.

同年での日本での消費量は, 国内生産量と輸入量の合 計で示されるるのとして, 牛肉 38 万トン, 豚肉 104 万 トン，鷄肉 78 万トンであった，羊肉は 9 万トンである. この数字の 1977 年の推定は去れぞれ 47 万トン, 128 万 トン，92万トン，10 万トンとなっている，羊肉の国内 生産量は年間 1 トンの横ばい状熊がここ数年間続いてい る.

日本語では，「肉」と言うと常識的には獣肉であるが， 広義江注家, 家禽, 野獣, 野鳥, 水産魚介類など, 食 用飞供されるすべての動物の筋肉が含まれている，とし てよいようである，法律上では，「屠音場法」では食用
に供される獣畜とは，牛，馬，豚，綇羊，山羊に限定さ れ，その解体された部分は肉，内藏，血液，骨，皮のい ずれかとなる。「家畜伝染病予防法」上では家畜とは， 牛, 水牛, 緬羊, 山羊, 豚, 鵎, アヒル, 七面鳥, ウズ ラ, ミシパチであり，「飼料安全法」の場合では家畜比 緬山羊は含まれず，政令により定められた家畜とは牛， 豚，蒩，ウズラ，ミシバチ，ブリ，マダイ、コイ、ウナ ギ, ニジマス拈よびフュである。

「食品衛生法」上の「食品」とは「すべての飲食物」 を意味し，食肉子食品として报われるが，「食品衛生六 法」といらような書物を操っていると，「食用としての 犬肉販売について」これをどう报うべきかとか，「食用 蛙の取扱いについて」などに関しての公的な見解の通達 が散見されて面白い。

うまい食べ物についての話題は常にニュースになると して新しい肉についての最近のトピックスのいくつかを ご紹介する。 
一般的に肉のらまさを決めるるのが，歯ざわりや舌ざ わりによって感じられる組織の物理性の他に, 化学的な 脂游の質と量によるところが大さいとする説は，多くの 人ふにより，経駰的に受け入れられているところであ

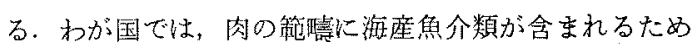
か，食品のうまさを，その土キス組成に求める研究も多 W.

肉の含有脂肪の面から牛, 羊, 山羊によって代表され る反勆動物の肉をみると，その脂質的な特徽は飽和脂肪 酸含量の多さに屴る。

従来, 牛の肥育用配合飼料中の脂肪量は $5 \%$ が限度で めりこの量を越えると嫌気状態にある反琶胃中で起こ る消化と醗醇，すなわち脂肪の加水分解と水素添加によ り生成する高度飽和脂肪酸が筋肉中に蓄積して，肉質を 劣化させるとされていた，1970 年にScottやCookな

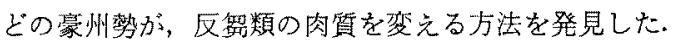

彼らが用いた動物はラムである. ラムとは 1 才未満の若 い羊を言い， 3 才以上の羊(主化羊毛をとった後の廃羊) がマトンで，1才になった羊はホら゙ットである．彼らは 不飽和脂肪酸の多い植物油をカでインでコーティング し，そのカゼインをホルマリンで変性させ，植物油をカ プセル化した. カプセル化された不飽和脂肪酸は変化を 受けることなく反婺胃をその委通過し，第 4 胃で単胃 動物の場合と同様に消化吸収さ礼，肉飞蓄積したそそし てフレーバーとアロマが一変した，新しいラムができ上 った。るちろんこの方法で羊を飼らと, ミルク中の不飽 和脂肪酸量す增加する. 1974 年になると，この方法は 米国で牛の肥育に適用され，成功を扣さめた。霜降肉生 産の新しい技術が生をれたといらことができる。

同年米国では 10 万頭のビイファロー（Beefalo）が生 産されたといら。ビイファトーとはバッファロー(アメ リカ野牛）と牛との交雑種で，この交配は多くの篤志家 により 100 年以上試みられ続けたが不成功に終り，上う やく 10 年前になって成功が得られたすのである. どイ ファローは3/8のバッファロー, 3/8のシャトレー, 2/8 のヘレフォードの血を引くとされているが，作出の詳細 については未だ公表されていない，その肉は $20 \%$ の蛋 白質之7\%の脂肪を含み，柔らかく，こくがあってうま く，牛肉上り安いといらので注目を集めているといら．

わが国では「いのぶた」の肉が新しい昧として宣伝さ

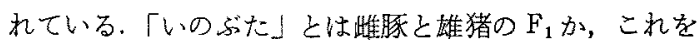
それぞれ厌し交配してつくられる雑種で，戦後数か所で 作出が試みられた。1972 年の和歌山目畜産試験場の報 告によると，豚の肉質改善を目的とした試験の結果，肉 は豚の淡紅色に比べて鮮紅色で臭気がなくよく締ま
り, 脂肪は霜降りで食味があっさりし，被愉者 50 名の らち 98\%が「うまい」と答えたという。

日本の食鳥業界で最近,「あじどり (味鳥)」といら言 葉が使われるようになった，大量生産，大量消費のブロ イラーに文句の范る古老達が，昔の地欍のらまかったこ とを思い出し，「比内舀」「薩摩鷄」「名古屋コーチン」 シャモ，カモなどをならかしんで，その味がブロイラー とは一味違らといらところから作られた言葉らしく，北 京ダック，フヒル，合鴨，七面鳥，ホロホロ鳥なよ゙るこ れ炕含まれる。

鹿児島県では，古来美味として名声の高かった地鵎の

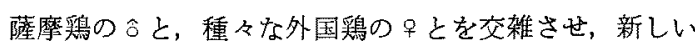
薩摩舀を作出する試みが 10 年来続けられている.シャ モとブロイラーとの交雑の試みも各地で盛んのようた。

北京ダックを含めて、わが国のアヒルの生産量は年間 約 50 万呮, 輸入量恃約 3000 トンと推定され，その主な 用途は中華料理店向けらしい. 1975 年に東京都蓄産試 験場が肉用アヒルの生産について報告を出した。

アイガモとは実体のはっきりしない食鳥である，台湾 ではマガモのるとパリケンの早との $F_{1}$ ということたが， 日本ではアとルそのるのであったり，家离化されたアオ クビガモであったり，またカモとアヒルの交雑種であっ たりするらしく，そのルーッは一定していない.アイガ モといら名前で多彩な肉が珍味として流通しているよう である.

昨令，わが国の食鳥界の一部でるてはやされているホ ロホ口鳥は，ブロイラーに続く「青い目」の食鳥の二番 手として期待を生んだが，未だその地位は安定したもの ではない。この鳥はフフリカ北西部原産のキジ科の鳥 で,ギリシャ・キーマの時代から，ヨーロッパでは食卓 にのぼっていたという，ある企業のパンフレットに、レ オナルド・ダ・ビンチの「最後の晚餐」には，このホロ 亦口鳥が描かれているといら記述があったのが面白い。 木口木口鳥は暑期の産卵率が高い。また卵款が鷄卵と比 較して $20 \%$ 厚く，暑期の保存以上く耐克る. 10 年活ど 前にオーストラリフで，夏期にニワトリの久点を補ら家 窉として研究しているといら話をきいた．現在フランス で，この肉の消費の伸びが著しい，同国での 1974 年に 却当ホトホワ鳥の消費は約 5000 万羽で，この数字は， この年フランスの国民各 1 人が各 1 羽のホロホロ鳥をた べたのに近い,フランスでは元来, 家庭での鬼肉の消費 が盛んであり飼養羽数約 1 億羽と言われているが，最 近, 疾病の流行 (myxomatosis) kより鬼肉の生産が減 少しこれがホロホロ鳥の消費の伸長の原因になったと 考えられている.この鳥の肉質は，キジとシャモの中間 
と表現する人るある。1974 年に伊豆シャボテン公園が 家离小口ホ口鳥の諸能力について報告を出している.

身関しては目下，生産者と消費者との間の䪞価の ギャッブが大きい，生虐者が期待するほどの消費の伸び がない、ブロイラーを基準として味と値段を判断するよ
らになった消費者にとって，末な゙味鳥の肉は珍味ではあ っても日常食品ではない、珍味としてとどする限り，味 鳥のマーケットは限られたものとしかなり充いいである らし，他の肉についても同様であるら。

(N.Y.)

\section{Taurine 欠乏によるネコの失明}

日本では105万世帯が200万匹のネコを飼い，キャッ ト・クラブが 15 団体あり，その会員数は約 1 万人だと いう、昨年間のわが国のキャット・フードの䒕上高は, 䄪 46 億円であった.

これは米国での話であるが，1960年代の初め，よ5 やくドライ・ドッグ・フードが普及し始めた頃，このド ッグ・フードだけで飼われたネコが次々と失明するとい ら事件が続いた. しかし，市販のキャット・フードで飼 われたネコには失明はなかった。1970 年代の初めにな って，精製飼料を用いた実験で，タッリンを投与すれば ネコに失明が起らないことが判明した。西る種の哺乳類 の網膜に，タウリンが比較的高濃度に含まれることは知 られていたが，その欠乏か゚失明につながることは新しい 発見であった. 市貶のキャット・フードには約 $0.1 \%$ の タウリンが含まれていた。

ネコには飳料中のメチオニンやシスチンからタウリン を合成する能力がない。

タウリンは 1824 年に Gmelin により牡牛の胆汁中 に発見された物質で，1846 年に Redtenbacherにより 含硫化合物であることが明らかにされた，古いかが国の 水産化学の書物には，この物質はタコの煮汁から製造さ れ, 結核, リューマチ, 神経痛, 腺病質, 特, 夜尿症な

第 1 表

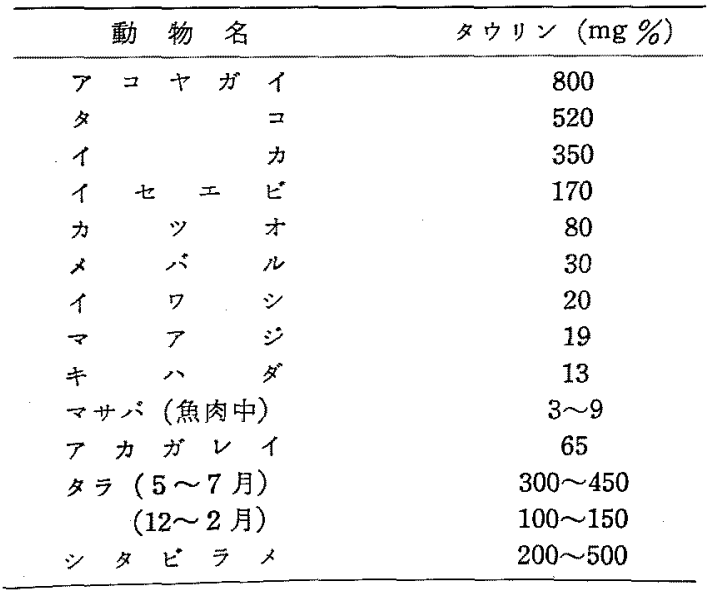

どに效くと記されている。タウリンはイカ，タコ，カ

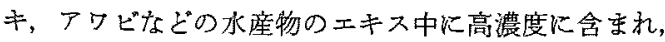

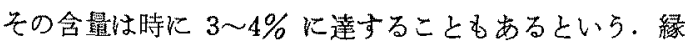
日などで漂ってくる「焼きイカ」の刺激臭は，この物質 の熱分解による含硫化合物犬゙とされている，第 1 表に， 文献に散見される，海産動物エキス中のタウリン含量を 集戴した。ネコがタウリンを要求するといらことを知っ た上で，改めてネコの食性を見直すと，ネコのイカ好 き，サカナ好きに性物学的な意味があるのかもしれな といら気になる，また海産動物の末梢神経中にはこの物 質がきわめて多く， $\mathrm{mg} \%$ で表して，カ二の脚：813，イ カ：1290、ロブスター：150 の数字がある.ニワトリで は6.5である.

別の話として，ネュの蛋自質要求量が相当に高いこと は，かなり以前から知られていた，1898 年に G. Bunge が「ブンゲの動物成舆律」とも呼ばるべき一見解を発表 したが，この説は，哺乳類では出生時の体重が 2 倍とな るのに必要な乳仔の成長日数は，ミルク中の蛋白質と灰 分含量によって定まる，とするあのであった。プンゲの オリジナル・テーブルではネコの場合，ミルクの蛋白質 含壘が最も多く9.5\%で，その所要日数も 7 日之一番短 くなっている

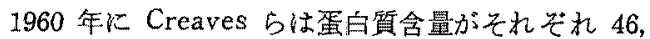
$39 ， 32 ， 26 ， 19 ， 13 \%$ と異なるニサでネコを飼ってみ た.その尿をぺーパー・クロマトグラフにかけてみると， メチルヒスチジン，タウリン，フェリニン(Felinine)が 常に3大スポットとして検出された，そして当時はこの フェリニンは, ペーパー・クロマトグラム上ではキッ ト・スポットと呼ばれた物質の本体であった。ネコ 1 匹 の1日当りのフェリニンの排浛量は $100 \sim 120 \mathrm{mg}$ とさ れている。

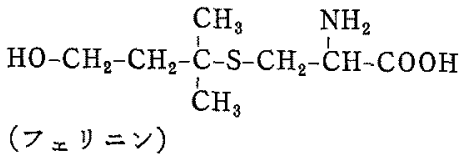

カゼインを唯一の蛋白質源として精製飼料でネコを飼 らと, 約3がでそのネコに retinal degenation が起 